\title{
PENGARUH SENAM BUGAR LANJUT USIA (LANSIA) TERHADAP KADAR ASAM URAT PENDERITA HIPERTENSI
}

\author{
${ }^{1}$ Hubert I. Tatara \\ ${ }^{2}$ Herlina I. S. Wungouw \\ ${ }^{2}$ Hedison Polii
}

\author{
${ }^{1}$ Kandidat Skripsi Kedokteran Universitas Sam Ratulangi Manado \\ ${ }^{2}$ Bagian Fisiologi Fakultas Kedokteran Universitas Sam Ratulangi Manado \\ Email: hubert_i_tatara@yahoo.com
}

\begin{abstract}
The increase of life expectancy contributes to complex impact on diseases suffered by the elderly. Although it is yet to be considered as a risk factor, data suggests that uric acid is one of the risk factors of cardiovascular disease. Exercise is an effort which prevents the increase of uric acid levels. 'Senam Lansia' (Elderly Aerobics) is a light, simple \& easy to apply to the elderly. This study has purposed to know about elderly aerobics effects on uric acid levels in patients with hypertension. This study is a one group pre-post test, that was conducted as a field at BPLU Senja Cerah. Elderly aerobics has been doing 3 times in a week for 3 weeks in 30 subjects. The result shows a significant decrease of uric acid levels before and after the exercise, with an average difference of $1,56 \mathrm{mg} / \mathrm{dl}$. The confidence interval value for lower is $0,84 \& 2,28$ for upper. Based on the result of statistic test, (p) value which is the signification value is 0,00 smaller than the value of alpha $(a=0,05)$. This study proves that elderly aerobics contributes significantly in the levels of uric acid in patients with hypertension.
\end{abstract}

Keywords: elderly, elderly aerobics, hypertension, uric acid

\begin{abstract}
Abstrak: Usia harapan hidup yang semakin meningkat, membawa dampak semakin kompleks dalam hal penyakit yang bisa diderita oleh orang lanjut usia. Meskipun belum dianggap sebagai faktor resiko, namun data yang ada menunjukkan asam urat merupakan salah satu faktor resiko penyakit kardiovaskular. Salah satu pencegahan dari meningkatnya kadar asam urat yakni dengan berolahraga. Senam lansia adalah olahraga ringan, mudah dilakukan dan tidak memberatkan untuk diterapkan pada lansia. Penelitian ini bertujuan untuk mengetahui pengaruh senam bugar lansia terhadap kadar asam urat penderita hipertensi. Penelitian bersifat eksperimental lapangan dengan rancangan one group pre-post test yang dilakukan pada 30 penderita hipertensi di BPLU Senja Cerah. Dilakukan senam bugar lansia 3 kali seminggu dengan lama latihan selama 3 minggu. Kadar asam urat sebelum dan sesudah senam diukur, dan dianalisa. Hasil yang didapat, terjadi penurunan bermakna kadar asam urat antara sebelum dan sesudah senam bugar lansia dengan selisih rata-rata sebesar $1,56 \mathrm{mg} / \mathrm{dl}$. Nilai confidence interval, yaitu 0,84 untuk lower dan 2,28 untuk upper. Nilai signifikasi (p) dari hasil uji statistik yaitu 0,00 lebih kecil dari nilai alpha $(\alpha=0,05)$. Penelitian ini membuktikan adanya pengaruh yang signifikan senam bugar lansia terhadap kadar asam urat penderita hipertensi.
\end{abstract}

Kata Kunci: asam urat, hipertensi, lansia, senam bugar lansia

Indonesia memasuki era dimana penduduk lanjut usia (aging structured population) mengalami peningkatan, dikarenakan jumlah penduduk yang berusia 60 tahun ke atas sekitar 8,9 \% pada tahun 2006. Jumlah penduduk lanjut usia (lansia) kurang lebih 19 juta dan pada tahun 2020 diperkirakan sebesar 28,8 juta $(11,34 \%){ }^{1}$ Usia harapan 
hidup yang semakin meningkat, membawa dampak semakin kompleks penyakit yang bisa diderita oleh orang lanjut usia, dan hipertensi merupakan salah satu penyakit yang lebih sering ditemukan. ${ }^{2}$

Hipertensi merupakan salah satu penyebab paling penting kematian dini di seluruh dunia terutama di Amerika Serikat. ${ }^{3,4}$ Hampir satu miliar penduduk dunia memiliki riwayat tekanan darah tinggi dimana dua pertiganya adalah negara berkembang. $^{3} \mathrm{Di}$ Indonesia, penderita hipertensi sudah semakin banyak dijumpai, terutama di kota-kota besar. ${ }^{5}$ Menurut World Health Organization (WHO), hipertensi membunuh hampir 8 juta orang setiap tahun di dunia dan hampir 1,5 juta orang setiap tahun dalam South-East Asia (SEA) Region. Sekitar sepertiga dari populasi orang dewasa di daerah SEA memiliki tekanan darah tinggi. Tahun 2025, diperkirakan 1,56 miliar orang dewasa akan hidup dengan hipertensi. ${ }^{3}$

Banyak penelitian menunjukkan adanya hubungan antara asam urat dengan penyakit kardiovaskular, termasuk hipertensi, sindrom metabolik, dan penyakit ginjal. ${ }^{6}$ Penelitian yang dilakukan oleh Heinig dan Johnson pada tahun 2006, menemukan bahwa tikus mengalami tekanan darah tinggi 3 sampai 5 minggu setelah mereka sedikit meningkatkan kadar asam urat dengan memberikan penghambat uricase, oxonic acid. ${ }^{7}$ Tekanan darah tinggi ini terjadi karena asam urat menyebabkan renal mengalami vasokonstriksi melalui penurunan enzim nitrit oksidase di endotel kapiler sehingga terjadi aktivasi sistem renin-angiotensin. ${ }^{6}$

Kebugaran jasmani juga sangat diperlukan untuk mencegah atau menunda penyakit-penyakit degeneratif dan penyakit kelainan metabolisme. Perlu adanya upayaupaya baik besifat perawatan, pengobatan, pola hidup sehat dan juga upaya lain, seperti senam lansia untuk mempertahankan kesehatan lansia tersebut. ${ }^{8,9}$ Penelitian yang dilakukan oleh Fajarina pada tahun 2011, mengenai analisis pola konsumsi dan pola aktivitas fisik dengan kadar asam urat pada lansia wanita peserta pemberdayaan lansia di Bogor, didapati rata-rata konsumsi purin perhari pada kelompok dengan kandungan asam urat yang tinggi lebih banyak dibandingkan dengan rata-rata konsumsi kelompok dengan kandungan asam urat normal, namun tidak diperoleh hubungan yang nyata $(\mathrm{p}>0,05)$ antara konsumsi purin dengan kadar asam urat dalam darah. ${ }^{10}$

Menurut penelitian dari Bosco dkk pada tahun 1970, yang meneliti kadar asam urat pada mahasiswa laki-laki yang sehat sebelum dan sesudah diberikan latihan fisik selama 8 minggu, membaginya ke dalam kelompok atletik, kelompok pelatihan dan kelompok kontrol. Ditemukan bahwa latihan fisik kronis menurunkan kadar asam urat 0,3-3,2 mg / $100 \mathrm{ml}$ dalam 80\% dari sampel kelompok atletik dan pelatihan. ${ }^{11}$

\section{METODE PENELITIAN}

Jenis penelitian yang dilakukan bersifat eksperimental lapangan dengan rancangan penelitian one group pre-post test. Penelitian ini dilaksanakan antara bulan November 2012 sampai bulan Desember 2012. Tempat penelitian di Balai Penyantunan Lanjut Usia (BPLU) Senja Cerah. Populasi penelitian ini adalah semua pasien lanjut usia (lansia) dengan riwayat penyakit hipertensi di BPLU Senja Cerah. Sampel penelitian diambil dari sebagian populasi yang sesuai dengan kriteria inklusi, seperti tekanan darah sistolik $\geq 130$ mmHg dan atau tekanan darah diastolik $\geq 90 \mathrm{mmHg}$, pasien lanjut usia dengan umur $\geq 60$ tahun, tidak ada keluhan untuk mengikuti senam lanjut usia, bersedia menjadi subjek dan menandatangani informed consent.

Definisi operasional lanjut usia (lansia) adalah seseorang yang berumur $\geq 60$ tahun ke atas. Pengelompokkan usia menggunakan pembagian menurut WHO, dengan usia 45-60 tahun (middle age), usia 60-75 tahun (elderly), usia 75-90 tahun (old), usia diatas 90 tahun (very old). Penderita hipertensi adalah orang yang telah didiagnosis oleh dokter dengan hipertensi dan memiliki tekanan darah 
sistolik $\geq 130 \mathrm{mmHg}$ dan atau tekanan darah diastolik $\geq 90 \mathrm{mmHg}$. Tidak ada keluhan untuk melakukan kegiatan berjalan. Kadar asam urat diambil sebelum dan setelah dilakukan senam bugar lansia. Kadar asam urat normal pada pria berkisar 3,5 sampai $7 \mathrm{mg} / \mathrm{dl}$ dan pada perempuan 2,6 sampai $6 \mathrm{mg} / \mathrm{dl}$. Senam bugar lansia dilakukan 3 kali satu minggu dengan durasi 20-30 menit selama 3 minggu.

\section{HASIL PENELITIAN}

Sampel diambil dari sebagian populasi yang telah memenuhi kriteria inklusi dan diperoleh sebanyak 33 subjek. Tiga responden dieksklusi, dikarenakan responden tersebut tidak mengikuti seluruh prosedur penelitian, sehingga sampel penelitian menjadi 30 responden. Berikut ini akan diuraikan hasil penelitian dalam bentuk tabulasi dan penjelasan.

\section{Distribusi kadar asam urat subjek berdasarkan umur}

Pengelompokkan usia ini menggunakan pembagian menurut WHO. Subjek yang termasuk kelompok elderly sebanyak 17 orang (56,7 \%) dengan jarak umur 60 sampai 74 tahun, sedangkan kelompok old sebanyak 13 orang (43,3 \%) dengan jarak umur 75 sampai 90 tahun. Nilai rerata kadar asam urat pada kelompok elderly adalah 9,62 mg/dl dan untuk kelompok old senilai $8,57 \mathrm{mg} / \mathrm{dl}$.

Tabel 1. Distribusi kadar asam urat subjek berdasarkan umur

\begin{tabular}{|c|c|c|c|}
\hline Umur & $\mathbf{F}$ & $\begin{array}{c}\mathbf{P} \\
(\%)\end{array}$ & $\begin{array}{c}\text { Rerata kadar asam urat } \\
\text { (mg/dl) }\end{array}$ \\
\hline Elderly & 17 & 56,7 & 9,62 \\
\hline Old & 13 & 43,3 & 8,57 \\
\hline
\end{tabular}

\section{Distribusi kadar asam urat subjek berdasarkan jenis kelamin}

Subjek dengan jenis kelamin laki-laki sebanyak 10 orang (33,3\%) dengan rerata kadar asam urat senilai 10,40 mg/dl. Subjek dengan jenis kelamin perempuan berjumlah lebih banyak, yakni 20 orang (66,7 \%) dan nilai rerata kadar asam urat sebesar 8,55 $\mathrm{mg} / \mathrm{dl}$.

Tabel 2. Distribusi kadar asam urat subjek berdasarkan jenis kelamin

\begin{tabular}{cccc}
\hline $\begin{array}{c}\text { Jenis } \\
\text { Kelamin }\end{array}$ & F & $\begin{array}{c}\mathbf{P} \\
\mathbf{( \% )}\end{array}$ & $\begin{array}{c}\text { Rerata kadar asam } \\
\text { urat (mg/d) }\end{array}$ \\
\hline Laki-laki & 10 & 33,3 & 10,40 \\
Perempuan & 20 & 66,7 & 8,55 \\
\hline F=Frekuensi. P=Persentase &
\end{tabular}

\section{Distribusi kadar asam urat subjek berdasarkan klasifikasi tekanan darah}

Diperoleh subjek dengan hipertensi stage 2 menduduki peringkat pertama dengan 43,3 \% (13 orang). Hipertensi stage 1 diperingkat kedua dengan 36,7 \% (11 orang) dan lansia yang merupakan prehipertensi sebanyak 6 orang (20\%). Rerata kadar asam urat untuk prehipertensi sebesar 9,56 $\mathrm{mg} / \mathrm{dl}$, hipertensi stage 1 sebesar $8,65 \mathrm{mg} / \mathrm{dl}$, dan hipertensi stage 2 sebesar 9,42 mg/dl.

Tabel 3. Distribusi subjek berdasarkan klasifikasi tekanan darah

\begin{tabular}{lccc}
\hline $\begin{array}{c}\text { Klasifikasi } \\
\text { hipertensi }\end{array}$ & F & $\begin{array}{c}\mathbf{P} \\
(\mathbf{\%})\end{array}$ & $\begin{array}{c}\text { Rerata kadar } \\
\text { asam urat (mg/d) }\end{array}$ \\
\hline $\begin{array}{l}\text { Prehipertensi } \\
\text { Hipertensi }\end{array}$ & 6 & 20 & \\
stage 1 & 11 & 36,7 & 9,56 \\
Hipertensi & 13 & 43,3 & 9,65 \\
stage 2 & & & \\
\hline
\end{tabular}

$\mathrm{F}=$ Frekuensi. $\mathrm{P}=$ Persentase

\section{Rerata kadar asam urat sebelum dan sesudah senam bugar lansia}

Didapatkan hasil bahwa pada laki-laki yang normal, sebelumnya 1 orang (10\%) dengan rerata $6,71 \mathrm{mg} / \mathrm{dl}$, bertambah menjadi 2 orang (20\%) dengan rerata 6,24 $\mathrm{mg} / \mathrm{dl}$. Laki-laki dengan hiperurisemia yang memiliki nilai rerata $10,81 \mathrm{mg} / \mathrm{dl}$, dari 9 
orang (90\%) menurun menjadi 8 orang (80\%) dengan nilai reratanya $9,27 \mathrm{mg} / \mathrm{dl}$. Hal yang sama juga terjadi pada perempuan, dimana kadar asam urat yang normal sebelumnya 3 orang (15\%) dengan rerata kadar asam urat $4,55 \mathrm{mg} / \mathrm{dl}$, bertambah menjadi 5 orang (25\%) dengan nilai rerata $4,86 \mathrm{mg} / \mathrm{dl}$. Perempuan dengan hiperurisemia dari 17 orang (85\%) menurun menjadi 15 orang (75\%) dimana rerata kadar asam uratnya $9,25 \mathrm{mg} / \mathrm{dl}$ dan 7,82 $\mathrm{mg} / \mathrm{dl}$.

Tabel 4. Rerata kadar asam urat sebelum dan sesudah senam bugar lansia

\begin{tabular}{ccccc}
\hline & \multicolumn{2}{c}{$\begin{array}{c}\text { Rerata sebelum } \\
\text { (mg/dl) }\end{array}$} & \multicolumn{2}{c}{$\begin{array}{r}\text { Rerata sesudah } \\
\text { (mg/dl) }\end{array}$} \\
\hline & Normal & $\begin{array}{c}\text { Hiper- } \\
\text { urisemia }\end{array}$ & Normal & $\begin{array}{c}\text { Hiper- } \\
\text { urisemia }\end{array}$ \\
& & & & 9,27 \\
L & 6,71 & 10,81 & 6,24 & 9,27 \\
& $(10 \%)$ & $(90 \%)$ & $(20 \%)$ & $(80 \%)$ \\
$\mathbf{P}$ & 4,55 & 9,25 & 4,86 & 7,82 \\
& $(15 \%)$ & $(85 \%)$ & $(25 \%)$ & $(75 \%)$ \\
\hline
\end{tabular}

\section{Kadar asam urat rata-rata}

Berdasarkan hasil olah data (gambar 1), didapatkan nilai rata-rata kadar asam urat sebelum senam sebesar 9,17 $\pm 3,196$, sedangkan nilai rata-rata kadar asam urat setelah senam selama 3 minggu sebesar $7,61 \pm 2,039$.

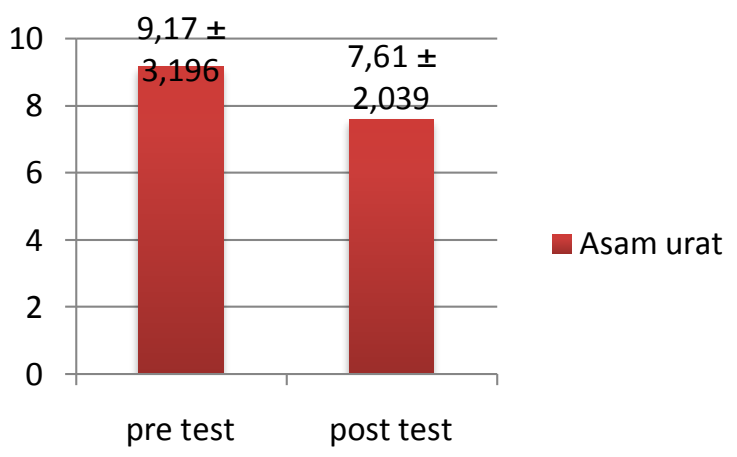

Gambar 1. Perbandingan kadar asam urat subjek penelitian.

\section{DISKUSI}

Berdasarkan tabel 1 di atas, baik kelompok elderly maupun kelompok old, memiliki rerata kadar asam urat yang tinggi. Dimana kelompok elderly sebesar 9,62 mg/dl dan kelompok old sebesar 8,57 $\mathrm{mg} / \mathrm{dl}$. Tingginya kadar asam urat ini, rentan dengan terjadinya penyakit asam urat. Menurut data tahunan dari Puskesmas Mijen Semarang tahun 2008-2010, jumlah penderita penyakit asam urat yaitu 52 orang, dimana $44,2 \%$ merupakan lanjut usia. $^{12}$ Berdasarkan data yang diperoleh dari Puskesmas Dr. Soetomo Surabaya pada tahun 2010, didapatkan data bahwa warga pralansia dan lansia yang memeriksakan diri pada tahun 2009 sebanyak 1584 orang, dimana sekitar 56,8\% warga menderita penyakit radang sendi. ${ }^{13}$

Rerata kadar asam urat pada laki-laki sesuai dengan tabel 2, lebih tinggi daripada rerata pada perempuan, dengan nilai 10,40 $\mathrm{mg} / \mathrm{dl}$ dan $8,55 \mathrm{mg} / \mathrm{dl}$. Hal ini tergantung dari pola hidup sehat yang mempengaruhi peningkatan produksi dan penurunan ekskresi asam urat atau kombinasi dari keduanya. $^{13-15}$

Umumnya laki-laki lebih banyak terserang asam urat, dan cenderung meningkat sejalan dengan peningkatan usia, sedangkan pada wanita persentasinya lebih kecil, dimana peningkatannya juga cenderung berjalan sejak dimulainya masa menopause. Hal ini karena wanita mempunyai hormon estrogen yang ikut membantu pembuangan asam urat lewat urin. Selama perempuan mempunyai hormon estrogen, maka pembuangan asam uratnya ikut terkontrol. $^{16}$

Pengklasifikasian tekanan darah dalam penelitian ini berdasarkan klasifikasi tekanan darah menurut The Seventh Report of the Joint National Committee on Prevention, Detection, Evaluation, and Treatment of High Blood Pressure (JNC 7) untuk pasien dewasa (umur $\geq 18$ tahun). Diperoleh hasil bahwa semua subjek memiliki tekanan darah tinggi, dan hipertensi stage 2 menduduki peringkat pertama dengan 43,3 \% (13 orang) seperti yang terlihat pada tabel 3. Rerata kadar asam urat untuk prehipertensi sebesar 9,56 mg/dl, hipertensi stage 1 sebesar $8,65 \mathrm{mg} / \mathrm{dl}$, dan hipertensi 
stage 2 sebesar 9,42 $\mathrm{mg} / \mathrm{dl}$.

Banyaknya responden dengan hipertensi stage 2 mungkin dikarenakan salah satu dari faktor resiko hipertensi stage 2 sesuai dengan penelitian dari Sugiharto A dkk, yang menyatakan bahwa umur semakin tua, riwayat keluarga dengan hipertensi, kebiasaan mengkonsumsi asin, lemak jenuh, kurangnya kebiasaan berolahraga, olah raga yang tidak sesuai dengan prosedur, obesitas (IMT > 25) dan wanita yang menggunakan pil KB selama 12 tahun berturut-turut merupakan faktor resiko hipertensi. ${ }^{17}$

Olahraga yang baik dilakukan oleh lansia antara lain berjalan kaki, senam lansia, senam jantung sehat, dan yoga, dimana dapat mengurangi resiko berbagai penyakit misalnya hiperurisemia, jantung dan lainlain. ${ }^{12}$ Berdasarkan tabel $4 \mathrm{di}$ atas, didapatkan hasil bahwa subjek laki-laki yang normal bertambah menjadi 2 orang (20\%) yang diikuti dengan penurunan rerata kadar asam urat menjadi 6,24 mg/dl. Rerata kadar asam urat laki-laki dengan hiperurisemia mengalami penurunan menjadi 9,27 mg/dl. Hal yang sama juga terjadi pada perempuan, dimana subjek yang normal bertambah menjadi 5 orang (25\%) namun tidak diikuti dengan penurunan rerata kadar asam urat. Rerata kadar asam urat perempuan dengan hiperurisemia mengalami penurunan menjadi $7,82 \mathrm{mg} / \mathrm{dl}$.

Kebugaran jasmani sangat diperlukan untuk mencegah atau menunda penyakitpenyakit degeneratif dan penyakit kelainan metabolisme. Upaya-upaya baik besifat perawatan, pengobatan, pola hidup sehat dan juga upaya lain, diperlukan untuk mempertahankan kesehatan lansia seperti senam lansia. ${ }^{9}$

Berdasarkan hasil penelitian mengenai pengaruh senam bugar lansia terhadap kadar asam urat penderita hipertensi ini, didapatkan bahwa nilai rata-rata kadar asam urat sebelum diberi perlakuan senam sebesar 9,17 \pm 3,196 dan setelah diberi perlakuan senam selama 3 minggu menurun menjadi 7,61 \pm 2,039 (lihat gambar 1). Nilai confidence interval 0,84 untuk lower, dan 2,28 untuk upper. Hasil ini tidak jauh berbeda dengan penelitian yang dilakukan
Bosco dkk, dimana terjadi penurunan kadar asam urat 0,3-3,2 mg / $100 \mathrm{ml}$ dalam 80\% dari sampel kelompok atletik dan pelatihan, setelah diberikan latihan fisik kronis selama 8 minggu.

Berdasarkan Penelitian Green dan Fraser pada tahun 1988, dimana pada kelompok 1 terjadi peningkatan kadar asam urat darah selama latihan, sedangkan pada kelompok 2 latihan sub-maksimal yang lama, gagal untuk merangsang peningkatan konsentrasi asam urat baik dalam hitungan hari maupun dalam beberapa hari. ${ }^{15}$ Dilihat dari penelitian Green dan Fraser tersebut, jelaslah kenapa pada penelitian ini tidak mengalami peningkatan kadar asam urat. Penelitian ini menggunakan intensitas latihan 3 kali seminggu selama 3 minggu dengan durasi latihan 20-30 menit. Menurut penelitian Haskell dkk pada tahun 2007, intensitas latihan sedang dengan minimum 30 menit selama 5 hari setiap minggu baik untuk semua orang dewasa dengan usia 18 hingga 65 tahun untuk menjaga kesehatan. ${ }^{18}$

Terjadinya penurunan kadar asam urat juga dikarenakan peneliti menggunakan perlakuan senam bugar lansia. Menurut buku karangan Dalimartha yang berjudul resep tumbuhan obat untuk asam urat, menerangkan bahwa olahraga yang terlalu berat akan menimbulkan penumpukan asam laktat di otot-otot sehingga pengeluaran asam urat melalui ginjal berkurang. ${ }^{19}$ Berbeda dengan itu, senam lansia adalah olahraga ringan, mudah dilakukan dan tidak memberatkan untuk diterapkan pada lansia. ${ }^{9}$

Hasil penelitian ini menunjukkan bahwa terjadi penurunan kadar asam urat ratarata sebesar $1,56 \mathrm{mg} / \mathrm{dl}$. Nilai signifikasi (p) dari hasil uji statistik yaitu 0,00 lebih kecil dari nilai alpha $(\alpha=0,05)$, sehingga menunjukkan adanya pengaruh yang signifikan senam bugar lansia terhadap kadar asam urat penderita hipertensi.

\section{SIMPULAN DAN SARAN}

Berdasarkan pembahasan di atas, dapat diambil kesimpulan bahwa ada pengaruh 
signifikan antara senam bugar lansia terhadap kadar asam urat penderita hipertensi $(p<0,05)$. Senam bugar lansia yang telah dilakukan tetap dipertahankan untuk menjaga kebugaran dan mencegah penyakit hipertensi dan hiperurisemia. Perlu juga penelitian lebih lanjut dengan jumlah sampel yang lebih banyak dan bervariasi.

\section{UCAPAN TERIMA KASIH}

Ucapan terima kasih disampaikan pada Dr. D. H. C. Pangemanan, M.Kes, AIFM, AIFO, Dr. Siantan Supit, AIFM, AIFO dan pada semua pihak yang baik secara langsung maupun tidak langsung telah menumbuhkan ide tau gagasan dalam pemikiran penulis sehingga dapat menyelesaikan artikel ini.

\section{DAFTAR PUSTAKA}

1. Kementerian Koordinator Bidang Kesejahteraan Rakyat. Lansia masa kini dan mendatang [homepage on the Internet]. 2005 [cited 2012 Nov 02]. Available from: http://oldkesra.menkokesra.go.id.

2. Kuswardhani RAT. Penatalaksanaan hipertensi pada lanjut usia [Tinjauan Pustaka]. J Peny Dalam. Denpasar: Universitas Udhayana. 2006;7(2):135-40.

3. World Health Organization Regional Office for South-East Asia. Hypertension fact sheet [homepage on the Internet]. 2011 Sept [updated 2011 Sep; cited 2012 Oct 20]. Available from: http://www.searo. who.int/linkfiles/non_communicable_disea ses_hypertension-fs.pdf

4. Price SA, Wilson LM. Patofisiologi: Konsep Klinis Proses-Proses Penyakit (Edisi Keenam). Jakarta: EGC, 2005; p.582-3.

5. Tambayong J. Patofisiologi [monograph online]. Jakarta: EGC, Year; p.94. [2012 Oct 20]. Available from: http://books.google.co.id/

6. Adiwijaya JA. Asam urat sebagai penanda penyakit kardiovaskular dan penyakit ginjal. Medika: Jurnal Kedokteran Indonesia [serial online]. 2011;37. Available from: http://www.jurnalmedika.com

7. Heinig M, Johnson RJ. Role of uric acid in hypertension, renal disease, and metabolic syndrome. Cleveland Clinic Journal of Medicine. 2006;73(12):1059-64.

8. Pranatahadi, Suharjana, Warsito AA. Pelatihan instruktur senam lansia bugar di desa Wijirejo Pandak. 2012

9. Prayoga AG, Ningrum AN, Arizona DD, Sriwahyuni E, Contesa E. Proposal terapi senam lansia dengan hipertensi di Panti Werdha Darma Bakti bagian atas km 7 Palembang. Palembang: Sekolah Tinggi Ilmu Kesehatan Perdhaki Charitas. 2012

10. Fajarina E. Analisis pola konsumsi dan pola aktivitas fisik dengan kadar asam urat pada lansia wanita peserta pemberdayaan lansia di Bogor. Bogor: Institut Pertanian Bogor. 2011.

11. Bosco JS, Greenleaf JE, Kaye RL, Averkin EG. Reduction of serum uric acid in young men during physical training [Abstract]. USA: Physical Education Laboratory and Student Health Service, San Jose State College, San Jose, Calif. 1970. [cited 2012 Des 16] Available from: http://www.sciencedirect.com/science/articl e/pii/0002914970908131.

12. Julianti R. Gambaran kadar asam urat pada lansia. Semarang: Universitas Muhammadiyah Semarang; 2011.

13. Festy P, Rosyiatul A, Aris A. Hubungan antara pola makan dengan kadar asam urat darah pada wanita postmenopause di posyandu lansia wilayah kerja puskesmas Dr. Soetomo Surabaya. Surabaya: FIK UM Surabaya, 2011; p.7.

14. Fitria AT. Efek ekstrak etanol daun dewa (Gynura pseudochina (L) DC) terhadap penurunan kadar asam urat mencit putih jantan galur Balb-C hiperurisemia. Surakarta: Universitas Muhammadiyah Surakarta; 2008.

15. Green HJ, Fraser IG. Differential effects of exercise intensity on serum uric acid concentration [Abstract]. Canada: University of Waterloo. 1988;20(1):55-59.

16. Nucleus precise news letter. Asam urat atau gout. Edisi 1. 2011;70:1-5. [cited 2013 Jan 31]. Available from: http://www. mirbrokers.com/data/Newsletter\%2070\%2 0Edisi\%201\%20\%20Asam\%20Urat\%20310120111.pdf

17. Sugiharto A, Hadisaputro S, Adi S, Chasani S. Faktor-faktor resiko hipertensi Grade II pada masyarakat di Kabupaten Karanganyar; 2008. 
318 Jurnal e-Biomedik (eBM), Volume 1, Nomor 1, Maret 2013, hlm. 312-318

18. Haskell WL, Lee IM, Pate RR, Powell KE, Blair SN, Franklin BA, et al. Physical activity and public health: updated recommendation for adults from the American college of sports medicine and the American heart association. American college of sports medicine and the American heart association. 2007;1423-34.

19. Dalimartha S. Resep tumbuhan obat untuk asam urat (Edisi Revisi). City: Penebar Swadaya, 2002; p. 7-9. 